\title{
RESPONSE IN ABERT'S SQUIRREL ABUNDANCE TO FOREST TREATMENTS ON CAMP NAVAJO, ARIZONA
}

\author{
R. Nathan Gwinn ${ }^{1,3}$, Jessica A. Gist ${ }^{1}$, Joel M. Diamond ${ }^{1}$, and Hannah Telle ${ }^{2}$
}

\begin{abstract}
Abert's squirrels (Sciurus aberti) are dependent upon ponderosa pine (Pinus ponderosa) forests in northern Arizona. Abert's squirrels feed primarily on the inner bark of ponderosa pine branches, as well as the tree's seeds and the hypogenous fungi associated with ponderosa pines. Abert's squirrels require interlocking tree canopies for escape cover and for feeding, particularly in winter months when snow impedes ground travel and the ability of Abert's squirrels to access fungi and hoarded food. In the Southwest, land managers in the ponderosa pine belt are implementing large-scale forest restoration treatments to reduce fire risk and return forest structure to pre-European settlement conditions. Restoration may decrease intrastand structural diversity and interstand heterogeneity for several decades, reducing the amount of habitat available to Abert's squirrels and reducing overall abundance. We estimated Abert's squirrel densities by enumerating squirrel feeding sign (branch clippings, clipped cones, truffle digging) over 9 years on 15 sites on Camp Navajo, an Arizona Army National Guard base in northern Arizona. Sites were treated at different times throughout the duration of the study. We evaluated the effects of forest restoration treatments on Abert's squirrel densities. We found no difference in Abert's squirrel densities on sites experiencing different treatment types. However, we did find a difference in Abert's squirrel densities between years.
\end{abstract}

Resumen.-Las ardillas de la especie Sciurus aberti dependen de los bosques de pino ponderosa (Pinus ponderosa) del norte de Arizona. Las ardillas se alimentan, principalmente, de la corteza interior de las ramas de pino ponderosa, así como de sus semillas y hongos hipogeos que crecen asociados a los pinos. Las ardillas necesitan conectar las copas de los árboles como cubierta de escape y para alimento, particularmente en los meses de invierno, cuando la nieve impide el transporte terrestre y el acceso a hongos y otros alimentos acumulados. En el suroeste, los administradores del cinturón de bosque de pino ponderosa están implementando tratamientos de restauración forestal a gran escala para reducir el riesgo de incendios y recuperar la estructura del bosque como estaba antes de que los asentamientos europeos tuvieran lugar. La restauración puede disminuir la diversidad estructural dentro de los grupos de árboles y la heterogeneidad entre los grupos de árboles por varias décadas, reduciendo la cantidad de hábitat disponible para las ardillas y la abundancia en general. Estimamos la densidad poblacional de ardillas enumerando los signos de consumo por las ardillas (trozos de ramas, conos cortados, excavación de trufa) durante nueve años en 15 zonas de Camp Navajo, en una base militar (Arizona Army National Guard), al norte de Arizona. Las zonas fueron tratadas en diferentes momentos a lo largo del estudio. Evaluamos los efectos de los tratamientos de restauración forestal en las densidades de ardillas. No encontramos diferencias en las densidades de ardillas entre zonas que experimentaron diferentes tratamientos. Sin embargo, encontramos una diferencia en las densidades de ardillas entre años.

Fire is an important component in southwestern ponderosa pine (Pinus ponderosa) forests. Historical and dendrochronological records indicate that these forests have been subject to frequent low-intensity ground fires (Swetnam and Baisan 1996, Covington 2003). Frequent fires maintain forest structure by limiting recruitment, reducing the number of small-diameter trees, and reducing fuels in the form of down woody debris and cast needles and twigs (Parsons and DeBenedetti 1979, Zimmerman 2003). Fire suppression efforts begun in the early 20th century have resulted in drastic changes to the fire regime of ponderosa pine forests, with fires less frequent and of higher severity than those that occurred under presettlement conditions (Covington and Moore 1994, Zimmerman 2003). The consequence of this change in fire regime is a forest structure with increased density of small trees and unnatural accumulation of litter, both of which contribute to the severity of wildfires (Parsons and DeBenedetti 1979, Zimmerman 2003). Fire has become more of a concern to land and wildlife managers, and consequently more studies have been conducted on the topic. In the southwestern United States, studies on the effects of fire on wildlife have proliferated in the last decade (Converse et al 2006, Covert-Bratland et al.

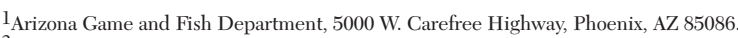

${ }^{2}$ Camp Navajo Army Depot, Bellemont, Coconino County, AZ 86015

${ }^{3}$ E-mail: rgwinn@azgfd.gov
} 
2006, Conway and Kirkpatrick 2007, Dickson et al. 2009, Kalies et al. 2010).

During the latter half of the 20th century, land managers implemented fuels reduction and forest restoration treatments on public lands to recreate historical forest structure, reintroduce fire regimes, and improve wildlife habitat (Swetnam et al. 1999). These treatments often consisted of prescribed fires, thinning treatments, or a combination of both (Allen et al. 2002, Covington 2003, Kalies et al. 2010). Understanding how various wildlife species respond to these treatments is a growing priority for land managers in forested systems (Lindenmayer and Possingham 1996, Ballard et al. 2000, Dees et al. 2001, Garvey et al. 2010).

Given their ubiquity, detectability, and use as a managed small-game species, Abert's squirrel (Sciurus aberti) has been the focus of many studies on forest treatments and wildlife in the Southwest (Dodd et al. 2006, Kalies et al. 2010, Loberger et al. 2011, Worden and Kleier 2012). Abert's squirrels are dependent upon ponderosa pine for virtually every aspect of their life history (Keith 1965, Patton 1977, Brown 1984, Allred and Gaud 1994, Dodd et al. 2003). The species uses both open- and closed-canopy ponderosa pine forests (Dodd et al. 1998) but is believed to require interlocking tree canopies for cover and escape from predators during winter months (Prather et al. 2006). Abert's squirrels are also adaptable in their habitat requirements (Nash and Seaman 1977, Allred and Pogany 1995, Pogany and Allred 1995, Dodd et al. 1998). This aspect of their life history makes them eminently suitable as a study species in investigations regarding wildlife responses to forest treatments.

In a long-term study on Camp Navajo Army National Guard Base in northern Arizona, we compared Abert's squirrel density estimates in untreated ponderosa pine forest stands to density estimates in forests undergoing restoration and fuels reduction (thinned, burned, thinned and burned).

\section{Methods}

\section{Study Area}

Camp Navajo is an Arizona Army National Guard base that is 11,522 ha in size and located approximately $16 \mathrm{~km}$ west of Flagstaff,
Arizona. The West Buffer of the installation is largely undeveloped and is dominated by ponderosa pine (Pinus ponderosa) forests containing a mixed understory of Gambel oak (Quercus gambelii) and New Mexican locust (Robinia neomexicana). Higher elevations (e.g., Volunteer Mountain) are characterized by mixed conifer forests comprised of $P$. ponderosa, southwestern white pine (Pinus strobiformis), Douglas-fir (Pseudotsuga menziesii), and white fir (Abies concolor). Beginning in 2002, the base began forest treatments that consisted of thinning, burning, or a combination of thinning and burning (Fig. 1).

\section{Density Estimation}

We used the same feeding sign index technique as Dodd et al. (1998) to estimate Abert's squirrel density. This design includes 64 survey plots, each 100-200 $\mathrm{m}$ in length, oriented along four 1120-m parallel transects at each site. Within each plot, four $1-\mathrm{m}^{2}$ points were spaced $17.5 \mathrm{~m}$ apart for a total of 256 sampling plots. Feed sign plots encompassed an area of $67 \mathrm{ha}$, consisting of 256 survey points. At each survey point, we determined presence or absence of Abert's squirrel feed sign (clippings, truffle digs, eaten cones) within $1 \mathrm{~m}^{2}$. The feeding sign age was determined by color for cones and pine boughs (new cones were reddish or brown in color, old cones were grey; new pine bough clippings were green, old ones were brown or yellow). Truffle digs were aged by the presence or absence of soil piles adjacent to the digs.

Transects were permanently marked with ID tags at the starting point. Surveys were conducted in 2002, 2003, 2005, 2006, 2007, 2008, 2009, 2011, and 2012 (9 seasons). In 2006 , additional survey points were added to overlap more treatment area. We entered presence/absence data into a regression model to estimate squirrel density.

\section{Evaluation of Treatments on Squirrel Densities}

We used a two-way analysis of variance (ANOVA) to compare squirrel densities in survey plots, testing for an interaction between treatment type (untreated, thinned, burned, and thinned and burned) and year. We ran a one-way ANOVA comparing squirrel densities and treatment and a separate oneway ANOVA comparing squirrel densities 




Fig. 1. Map of study sites and treatments on Camp Navajo, Arizona. Map by Martin Piorkowski.

and year. In order to pinpoint significant differences within the one-way ANOVAs, we used Tukey's HSD tests for post hoc analyses.

\section{RESUlTS}

Squirrel densities averaged 0.08 squirrels per ha and ranged from 0 to 0.4 squirrels per ha in our 15 original and alternative survey plots across all years and treatment types. We found no interaction between year and treatment in relation to squirrel densities (two-way ANOVA: $\left.F_{3,20}=0.10 ; P=0.96\right)$. Similarly, we found no significant effect of treatment type on proportion of sites with squirrel feeding sign (one-way ANOVA: $F_{3,83}=0.071 ; P=$ 0.98). However, we did detect a significant effect of year on the proportion of sites with squirrel feeding sign (one-way ANOVA: $F_{1,85}$ $=5.27, P=0.02$; Fig. 2 ). A post hoc Tukey HSD test showed that 2008 and 2009 differed significantly in squirrel densities from the other 7 years of our study (Table 1).

\section{DisCusSION}

We documented the change in density of Abert's squirrels over a 9-year period. This change in density however was not associated with the different treatment types but was ultimately related to different years. Other studies report habitat preference of Abert's squirrels to include high basal areas, mature trees with interlocking crowns, and understory with little down and woody debris (Patton and Green, 1970, Patton 1977, Prather et al. 2006). Silvicultural techniques such as thinning and prescribed burns often result in degradation of Abert's squirrel habitat by creating more open stands with reduced basal area and decreased crown overlap (Covington et al. 1997, Mast et al. 1999, Moore et al. 1999, Dodd et al. 2003, Mast 2003). Both Dodd et al. (2006) and Kalies et al. (2010) found negative responses in both the densities and observability of Abert's squirrels after prescribed burns. However, according to our data, variation 


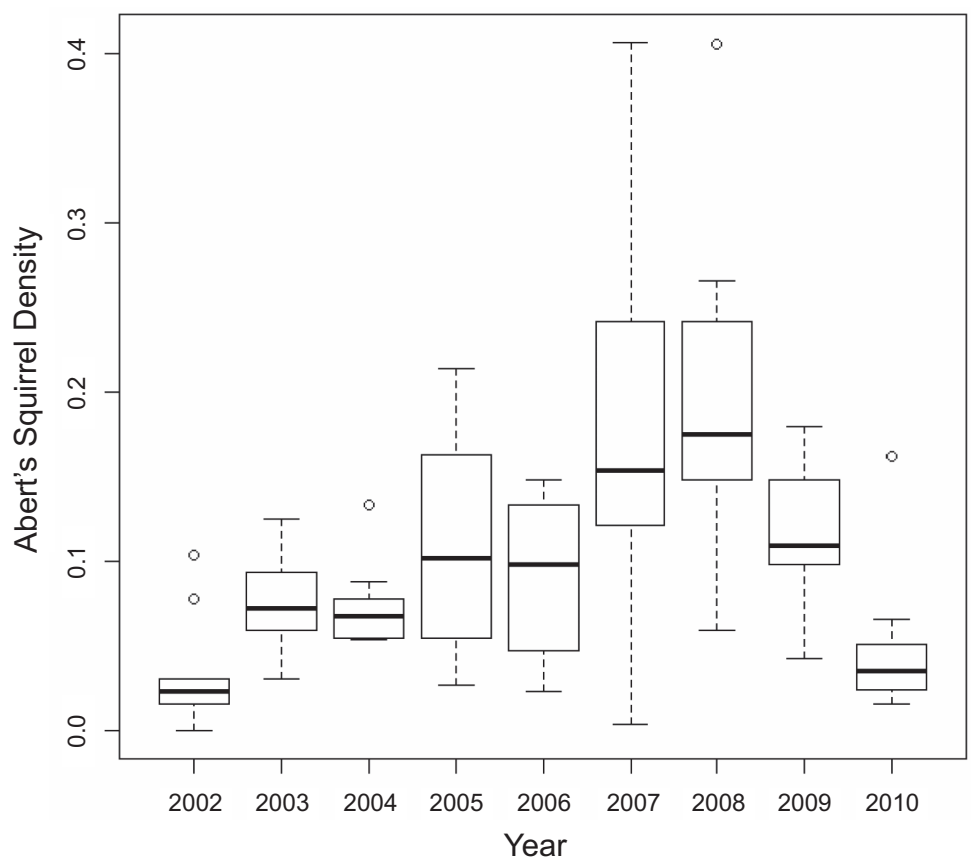

Fig. 2. Results of a one-way ANOVA by year on Abert's squirrel densities on all sites $\left(F_{1,185}=5.27, P=0.02\right)$.

TABLE 1. Tukey HSD multiple comparisons of means (95\% family-wise confidence level) of difference of Abert's squirrel densities for all sites by year.

\begin{tabular}{lcccc}
\hline Year & Difference & Lower 95\% CL & Upper 95\% CL & Adj. P value \\
\hline $2008-2002$ & 0.1384 & 0.049685129 & 0.22711487 & 0.0001265 \\
$2009-2002$ & 0.1623 & 0.073585129 & 0.25101487 & 0.0000040 \\
$2008-2003$ & 0.0927 & 0.003985129 & 0.18141487 & 0.0337065 \\
$2009-2003$ & 0.1166 & 0.027885129 & 0.20531487 & 0.0022375 \\
$2008-2005$ & 0.0970 & 0.008285129 & 0.18571487 & 0.0215773 \\
$2009-2005$ & 0.1209 & 0.032185129 & 0.20961487 & 0.0013025 \\
$2009-2006$ & 0.0857 & -0.003014871 & 0.17441487 & 0.0665138 \\
$2009-2007$ & 0.1002 & 0.011485129 & 0.18891487 & 0.0152821 \\
$2012-2008$ & -0.1232 & -0.211914871 & -0.03448513 & 0.0009697 \\
$2012-2009$ & -0.1471 & -0.235814871 & -0.05838513 & 0.0003720 \\
\hline
\end{tabular}

in some unknown factor(s) between years, and not forest treatments, affected Abert's squirrel densities on Camp Navajo. Populations of Abert's squirrels can fluctuate within and between years due to drought conditions, hypogeous fungus production, and winter snowpack (Keith 1965, Nash and Seaman 1977, Stephenson and Brown 1980). Our findings indicate that a stochastic factor such as climate or food production influenced Abert's squirrel densities over the course of our study.

In the American Southwest, the frequency and severity of wildfires have changed greatly since fire suppression efforts began in the 20th century (Parsons and DeBenedetti 1979, Zimmerman 2003). Fires have become much more severe and destructive than fire events that occurred naturally in presettlement times (Parsons and DeBenedetti 1979, Zimmerman 2003). Large-scale silvicultural techniques designed to mimic natural fire regimes and restore presettlement forest structure have been rightfully implemented by various land management agencies. Our study found that these treatments did not affect Abert's squirrel densities, but rather an unknown stochastic factor such as climate or food production had a larger influence on Abert's squirrel densities 
on our Camp Navajo sites. Future studies should examine these other factors that have the potential to affect Abert's squirrel densities. The collection of these data in concert with forest treatments will better elucidate the effects of forest management techniques on Abert's squirrels and will allow for greater inference based on their results. Moreover, the use of treated areas by Abert's squirrels in all seasons (foraging movements, nesting, reproduction, etc.) should be the subject of a long-term investigation rather than focusing solely on localized density trends. This extended scope would give investigators a better idea of how natural variables interact with treatment effects.

\section{ACKNOWLEDGMENTS}

We thank Martin Piorkowski for help with analyses, Wes McQueen and Lias Hastings for field data collection, and Janet Lynn for her role in project facilitation. We also thank Tim Wade, Ray Schweinsburg, Michael F. Ingraldi, Renee Wilcox, and Pam Kennedy, Wildlife Contracts Branch, Arizona Game and Fish Department, for project administration, development, and draft review. Project funding was provided through the Interagency Service Agreement (\# M13-0042) between the Arizona Department of Emergency and Military Affairs and the Arizona Game and Fish Department (Project \#AZ655060043). This project was funded by Arizona Army National Guard.

\section{Literature Cited}

Allen, C.D., M. Savage, D.A. Falk, K.F. Suckling, T.W. Swetnam, T. Schulke, P.B. Stacey, P. Morgan, M. Hoffman, and J.T. Klingel. 2002. Ecological restoration of southwestern ponderosa pine ecosystems: a broad perspective. Ecological Applications 12:1418-1433.

Allred, W.S., AND W.S. Gaud. 1994. Characteristics of ponderosa pines and Abert squirrel herbivory. Southwestern Naturalist 39:89-100.

Allred, W.S., AND G. Pogany. 1995. Early estrus in a female Abert squirrel (Sciurus aberti aberti). Southwestern Naturalist 41:90-91.

Ballard, W.B., P.R. Krausman, S. Boe, S. Cunningham, AND H.A. WhitLaW. 2000. Short-term response of gray wolves, Canis lupus, to wildfire in northwestern Alaska. Canadian Field-Naturalist 114:241-247.

Brown, D.E. 1984. Arizona's tree squirrels. Arizona Game and Fish Department, Phoenix, AZ.

Converse, S.J., W.M. Block, and G.C. White. 2006. Small mammal population and habitat responses to forest thinning and prescribed fire. Forest Ecology and Management 228:263-273.
Conway, C.J., And C. KirkPatrick. 2007. Effect of forest fire suppression on buff-breasted flycatchers. Journal of Wildlife Management 71:445-457.

Covert-Bratland, K.A., W.M. Block, and T.C. Theimer. 2006. Hairy woodpecker winter ecology in ponderosa pine forests representing different ages since wildfire. Journal of Wildlife Management 70:1379-1392.

Covington, W.W. 2003. The evolutionary and historical context. Pages 26-47 in P. Friederici, editor, Ecological restoration of Southwestern ponderosa pine forests. Island Press, Washington, DC.

Covington, W.W., P.Z. Fule, M.M. Moore, S.C. Hart, T.E. Kolb, J.N. Mast, S.S. SACKetT, and M.R. Wagner. 1997. Restoring ecosystem health in ponderosa pine forests of the Southwest. Journal of Forestry 95:23-29.

Covington, W.W., AND M.M. Moore. 1994. Southwestern ponderosa pine forest structure: changes since EuroAmerican settlement. Journal of Forestry 92:39-47.

Dees, C.S., J.D. Clark, and F.T. Van Manen. 2001. Florida panther habitat use in response to prescribed fire. Journal of Wildlife Management 65:141-147.

Dickson, B.G., B.R. NoOn, C.H. Flather, S. Jentsch, AND W.M. BLOCK. 2009. Quantifying the multi-scale response of avifauna to prescribed fire experiments in the southwest United States. Ecological Applications 19:608-621.

Dodd, N.L., S.S. Rosenstock, C.R. Miller, and R.E. SchweInsburg. 1998. Tassel-eared squirrel population dynamics in Arizona: index techniques and relationships to habitat condition. Research Branch Technical Report \#27, Arizona Game and Fish Department, Phoenix, AZ.

Dodd, N.L., R.E. Schweinsburg, and S. Boe. 2006. Landscape-scale forest habitat relationships to tassel-eared squirrel populations: implications for ponderosa pine forest restoration. Restoration Ecology 14:537-547.

Dodd, N.L., J.S. States, and S.S. Rosenstock. 2003. Tassel-eared squirrel population, habitat condition, and dietary relationships in north-central Arizona. Journal of Wildlife Management 67:622-633.

Garvey, N., D. Ben-Ami, D. Ramp, and D.B. Croft. 2010. Survival behaviour of swamp wallabies during prescribed burning and wildfire. Wildlife Research 37: $1-12$.

Kalies, E.L., C.L. Chambers, and W.W. Covington. 2010. Wildlife responses to thinning and burning treatments in southwestern conifer forests: a metaanalysis. Forest Ecology and Management 259: 333-342.

KeITH, J.O. 1965. The Abert squirrel and its dependence on ponderosa pine. Ecology 46:150-163.

Lindenmayer, D.B., And H.P. Possingham. 1996. Ranking conservation and timber management options for Leadbeater's possum in southeastern Australia using population viability analysis. Conservation Biology 10:235-251.

Loberger, C.D., T.C. Theimer, S.S. Rosenstock, and C.S. Wightman. 2011. Use of restoration-treated ponderosa pine forest by tassel-eared squirrels. Journal of Mammalogy 92:1021-1027.

Mast, J.N. 2003. Tree health and forest structure. Pages 215-232 in P. Friederici, editor, Ecological restoration of Southwestern ponderosa pine forests. Island Press, Washington, DC.

Mast, J.N., P.Z. Fulé, M.M. Moore, W.W. Covington, AND A. WALTZ. 1999. Restoration of presettlement 
age structure of an Arizona ponderosa pine forest. Ecological Applications 9:228-239.

Moore, M.M., W.W. Covington, and P.Z. Fulé. 1999. Reference conditions and ecological restoration: a southwestern ponderosa pine perspective. Ecological Applications 9:1266-1277.

Nash, D.J., AND R.N. Seaman. 1977. Sciurus aberti. Mammalian Species 80:1-5.

Parsons, D.J., And S.H. DeBenedetti. 1979. Impact of fire suppression on a mixed conifer forest. Forest Ecology and Management 2:21-33.

Patton, D.R. 1977. Managing Southwestern ponderosa pine for the Abert squirrel. Journal of Forestry 75: 264-267.

Patton, D.R., and W. Green. 1970. Abert's squirrel prefer mature ponderosa pine. Research Note RM169, USDA Forest Service, Rocky Mountain Forest and Range Experiment Station. 3 pp.

Pogany, G.C., And W.S. AllRed. 1995. Abert squirrels of the Colorado Plateau: their reproductive cycle. Pages 293-305 in C. Van Riper, editor, Proceedings of the Second Biennial Conference on Research in Colorado Plateau Parks. National Biological Service Information Transfer Center, Fort Collins, CO.

Prather, J.W., N.L. DodD, B.G. Dickson, H.M. Hampton, Y. XU, E.N. Aumack, AND T.D. Sisk. 2006. Landscape models to predict the influence of forest structure on tassel-eared squirrel populations. Journal of Wildlife Management 70:723-731.

Stephenson, R.L., And D.E. Brown. 1980. Snow cover as a factor influencing mortality of Abert's squirrels. Journal of Wildlife Management 44:951-955.

Swetnam, T.W., C.D. Allen, and J.L. Betancourt. 1999. Applied historical ecology: using the past to manage the future. Ecological Applications 9:1189-1206.

Swetnam, T.W., AND C.H. BaIsan. 1996. Historical fire regime patterns in the southwestern United States since A.D. 1700. Pages 11-32 in C.D. Allen, editor, Fire Effects in Southwestern Forests: Proceedings of the Second La Mesa Fire Symposium. General Technical Report RM-GTR-286, USDA Forest Service, Fort Collins, CO.

Worden, K.J., AND C. KLeIER. 2012. Impact of thinning ponderosa pines (Pinus ponderosa) on populations of Abert's squirrels (Sciurus aberti). Southwestern Naturalist 57:380-384.

Zimmerman, G.T. 2003. Fuels and fire behavior. Pages 126-143 in P. Friederici, editor, Ecological restoration of Southwestern ponderosa pine forests. Island Press, Washington, DC.

Received 11 October 2014 Accepted 20 January 2016 